\title{
Pregnancy Outcomes in Systemic Vasculitides
}

\author{
Carolyn Ross $^{1} \cdot$ Rohan D'Souza ${ }^{2} \cdot$ Christian Pagnoux $^{1}$ \\ Published online: 26 August 2020 \\ (C) Springer Science+Business Media, LLC, part of Springer Nature 2020
}

\begin{abstract}
Purpose of Review In recent years, improvements in the recognition of primary vasculitides and increased treatment options have led to greater survival rates and a better quality of life for patients. Therefore, pregnancy in women with vasculitis has become a more frequent consideration or event. Literature on pregnancy outcomes in this population has grown and allowed us, in this article, to review the effects of pregnancy on disease activity, as well as maternal and fetal outcomes for each type of vasculitides. Recent Findings Successful pregnancies in patients with vasculitides are possible, especially when conception is planned, and the disease is in remission. The risk of vasculitis flare is highly dependent on the type of vasculitis, but overall limited. The most frequent complication associated with large-vessel vasculitis (mainly Takayasu arteritis) is hypertension and preeclampsia. Preterm deliveries and intrauterine growth restriction occur more frequently with small- and medium-vessel vasculitis.

Summary Pregnancies in patients with vasculitis should be considered high risk and followed by a multidisciplinary team with expertise in the field. Flares should be managed as in the non-pregnant population, while avoiding medications with unknown safety in pregnancy or known teratogens. Although commonly prescribed for the prevention of preeclampsia, there is limited evidence supporting the use of low-dose aspirin for pregnant women with vasculitis. Prospective registries or studies are needed, to better assess the value of aspirin, the place and long-term impact of new biologics and, to identify predictors of pregnancy outcomes other than disease status at conception.
\end{abstract}

Keywords Pregnancy $\cdot$ Vasculitides $\cdot$ Vasculitis $\cdot$ Takayasu $\cdot$ Behçet's disease $\cdot$ ANCA-associated vasculitis

\section{Introduction}

Primary systemic vasculitides are a group of rare heterogeneous disorders classified mainly according to their affected vessel sizes [1]. In the past years, improvements in the diagnostic process and increased treatment options have led to an earlier detection, better survival, and less fertility concerns [2, 3•, 4]. Consequently, these diseases now affect more women of childbearing age and there has been a progressive increase in the number of pregnancies seen in this population [5].

This article is part of the Topical Collection on Vasculitis

Christian Pagnoux

Christian.Pagnoux@ sinaihealth.ca

1 Vasculitis Clinic, Division of Rheumatology, Department of Medicine, Mount Sinai Hospital, University of Toronto, Toronto, ON, Canada

2 Division of Maternal and Fetal Medicine, Department of Obstetrics and Gynecology, Mount Sinai Hospital, University of Toronto, Toronto, ON, Canada
Among the various primary vasculitides, those that can affect young women in their reproductive years are mainly Takayasu arteritis (TAK), polyarteritis nodosa (PAN), ANCA-associated vasculitis (AAV), immune-complex small-vessel vasculitis (IgA vasculitis), and Behçet's disease (BD) [6]. Most of the published literature on pregnancy outcomes are in patients with TAK or BD, because they occur at an earlier age $[2,5]$.

Ideally, prior to pregnancy, the disease should be in sustained remission to increase the chances of favorable outcomes [5]. The patient should meet with a team of specialists with experience in vasculitides and high-risk pregnancies to review medications, assess the risk of flares, and discuss the potential risks of adverse outcomes $[7 \cdot \bullet, 8]$.

Herein, we review the published literature on pregnancy outcomes in systemic vasculitides, highlighting possible characteristics associated with greater risks for adverse outcomes and impact of pregnancy on disease activity (Table 1). We also discuss how to optimize the management of pregnancy in these patients, their monitoring, and follow-up to prevent or detect early disease flares. Finally, we discuss more in depth the maternal and fetal outcomes in BD, TAK, and AAV. 
Table 1 Pregnancy outcomes in patients with systemic vasculitides

\begin{tabular}{|c|c|c|c|c|c|}
\hline Type of vasculitis & References & Risk of vasculitis flare & Maternal outcomes & Fetal outcomes & Comments \\
\hline \multicolumn{6}{|c|}{ Large-vessel vasculitis } \\
\hline Giant cell arteritis (GCA) & {$[5,14]$} & $\mathrm{N} / \mathrm{A}$ & $\mathrm{N} / \mathrm{A}$ & $\mathrm{N} / \mathrm{A}$ & $\begin{array}{l}\text { Usual onset in } \\
\text { patients }>50 \text { years } \\
\text { Multicentric case-control } \\
\text { study in France } \\
\text { showed that history of } \\
\geq 4 \text { pregnancies may } \\
\text { have protective effect } \\
\text { in the development of } \\
\text { GCA and/or } \\
\text { polymyalgia } \\
\text { rheumatica }\end{array}$ \\
\hline Takayasu arteritis (TAK) & $\begin{array}{c}{[15 \bullet, 16,} \\
17 \bullet \bullet \\
18,19, \\
20 \bullet]\end{array}$ & $\begin{array}{l}\text { Most patients are } \\
\text { diagnosed prior to } \\
\text { conception } \\
\text { Flares between } 3 \text { and }\end{array}$ & $\begin{array}{l}\text { Cesarean deliveries: } \\
\text { 35-50\% } \\
\text { Spontaneous } \\
\text { miscarriages: } 8-30 \%\end{array}$ & $\begin{array}{l}\text { Intrauterine fetal deaths: } \\
\quad 4-5 \% \\
\text { LBW and IUGR: } 20 \%\end{array}$ & $\begin{array}{l}\text { Most published reports of } \\
\text { pregnancies in } \\
\text { vasculitis are on TAK } \\
\text { (and BD) }\end{array}$ \\
\hline
\end{tabular}

$$
25 \%
$$

Most frequent

Therapeutic abortions: complication: maternal Preterm deliveries: hypertension and 4-30\% preeclampsia (40 and $20 \%$, respectively)

Medium-vessel vasculitis

Polyarteritis nodosa (PAN)

\section{$[2,4,5$, $7 \cdot \bullet, 8$, \\ 21,22 , \\ $23 \cdot, 24]$}

Disease onset during pregnancy or active disease at conception have resulted in maternal deaths ( 7 cases reported before 1982), mostly from renal failure or complications from hypertension

Recent evidence suggests that pregnancy outcomes are favorable when conceived during remission with rare disease relapsed

Kawasaki disease (KD) [25-31] Anecdotal cases of disease onset during pregnancy or postpartum

No cases of disease recurrence during pregnancy

Most studies show no major cardiovascular events. However, they have been reported in up to $10 \%$.

Case reports describe complications, such as ventricular fibrillation, other arrhythmias, thrombosis, myocardial infarction, and heart failure
Series of 19 pregnancies:

Spontaneous miscarriages: up to $16 \%$

Therapeutic abortions: $10 \%$

Preterm deliveries are common (50-100\% in small series)

Severe complications reported:

preeclampsia, renal deterioration, rupture of a pancreatic artery aneurysms in a patient with disease onset during pregnancy (27 weeks)

Uneventful pregnancies have been described even in patients with coronary aneurysms or previous bypass grafting secondary to coronary stenosis

One maternal death from thrombosis of a giant aneurysm in the left main coronary artery $16 \mathrm{~h}$ after delivery

Series of 72 pregnancies:

Cesarean deliveries: $40 \%$

Preterm deliveries: $10 \%$

Good fetal outcomes

Congenital anomalies: $3 \%$ of neonates

Children born to mothers with $\mathrm{KD}$ have a 2 -fold increased risk of the disease deaths are reported with one case associated with placental vasculitis

LBW: common
Literature is scarce Cutaneous PAN usually has good pregnancy outcome with possible flares limited to the skin.

May present as a breast lesion in postpartum

Anecdotal neonatal cases of transient cutaneous involvement are described with mothers affected with cutaneous PAN that flared during pregnancy (reported before 1994)

Scarce literature consisting mostly of case reports

Specific recommendations for anticoagulation are not available. Low-dose aspirin should be considered in all patients with stenosis or coronary aneurysms and thrombosis risk should be assessed before conception.

Epidural anesthesia with assisted second stage of labor is recommended to limit hemodynamic complications in 
Table 1 (continued)

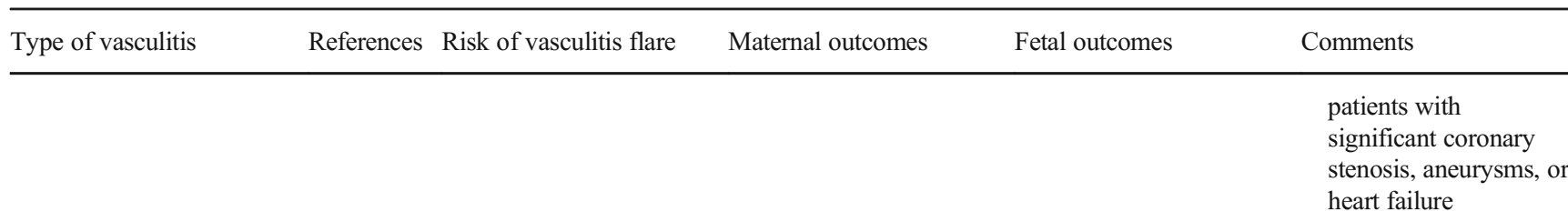

Small-vessel vasculitis

ANCA-associated vasculitis (AAV)

Microscopic polyangiitis (MPA)

\begin{tabular}{|c|c|c|}
\hline & 33] & $\begin{array}{l}\text { with worse outcomes) } \\
\text { and in postpartum } \\
\text { Rare flares when disease } \\
\text { in remission; less than } \\
50 \% \text { flare (mostly } \\
\text { when disease is active) }\end{array}$ \\
\hline $\begin{array}{r}\text { Granulomatosis with } \\
\text { polyangiitis (GPA) }\end{array}$ & $\begin{array}{l}{[2,4,5,} \\
7 \bullet \bullet, 34, \\
35, \\
36 \bullet \bullet]\end{array}$ & $\begin{array}{l}\text { Disease onset during } \\
\text { pregnancy (30\%) } \\
\text { occurs mostly in the } \\
\text { second or third } \\
\text { trimesters. Diagnosis } \\
\text { in postpartum less than } \\
20 \% \text { of cases } \\
\text { Flares are reported in } \\
25-40 \% \text { of patients if } \\
\text { the disease is in } \\
\text { remission at } \\
\text { conception and up to } \\
100 \% \text { if disease is } \\
\text { active } \\
\text { Flares occur mostly in the } \\
\text { first and second } \\
\text { trimesters (mostly } \\
\text { pulmonary } \\
\text { involvement then skin } \\
\text { lesions and arthralgias) }\end{array}$ \\
\hline $\begin{array}{l}\text { Eosinophilic } \\
\text { granulomatosis with } \\
\text { polyangiitis (EGPA) }\end{array}$ & $\begin{array}{l}{[2,4,5,} \\
\quad 7 \bullet \bullet, 37, \\
38,39 \bullet \\
\quad 40]\end{array}$ & $\begin{array}{l}\text { Most diagnoses made } \\
\text { before pregnancy. } \\
\text { About } 30-40 \% \text { of } \\
\text { cases with final } \\
\text { diagnosis during } \\
\text { pregnancy before the } \\
\text { third trimester. Onset } \\
\text { rarely reported in } \\
\text { postpartum } \\
\text { Flares reported in } \\
25-50 \% \text { of patients, } \\
\text { mostly with lung } \\
\text { infiltration/asthma } \\
\text { exacerbation or } \\
\text { neuropathy (90\%) } \\
\text { Cardiac involvement } \\
\text { associated with poor } \\
\text { prognostic }\end{array}$ \\
\hline
\end{tabular}

Immune complex vasculitides

\footnotetext{
Anti-glomerular

basement membrane

(anti-GBM) disease
} disease onset during pregnancy, especially
$[2,3 \cdot, 4,5$, Rare cases of diagnosis in Preeclampsia: up to $45 \%$ $7 \cdot \bullet, 32$, pregnancy (associated Therapeutic abortions: $5-10 \%$

Spontaneous miscarriages: $10 \%$

Preterm deliveries: $30 \%$

One maternal death from pulmonary infection

Preterm deliveries: $40 \%$

Miscarriages: 5-10\%

Therapeutic abortions: $10 \%$

When disease is active, up to $40-100 \%$ of miscarriages have been reported

Preeclampsia: $20 \%$

Cesarean deliveries: 40-50\%

One maternal death from intracranial bleeding (25 weeks) and one maternal death from a vasculitis flare (post abortion)

Preeclampsia: rare $(<5 \%)$ Rare cases of intrauterine Fetal loss: $10-15 \%$ (up to deaths $50 \%$ if disease is IUGR: $10-25 \%$ active)

Therapeutic abortions: 5-10\%

One maternal death from myocardial infarction and one death from cardiac failure 3 months postpartum

Preterm deliveries: $10-40 \%$

Cesarean deliveries: 15-40\%

Almost all deliveries described resulted in preterm labor in the second trimester, with some pregnancies resulting in therapeutic abortions
LBW: up to $65 \%$

Possible placental transfer of anti-MPO antibodies with one newborn developing pulmonary-renal syndrome

IUGR and LBW:

$10-25 \%$

Rare intrauterine deaths

LBW: $10-30 \%$
IUGR with LBW: 75-80\%

2 newborns were

described as having anti-GBM antibodies without any manifestations
Few cases described

It is possible that previous reports (before 1994) classified MPA as PAN

GPA is the AAV with the most published reports of pregnancy and AAV

Renal involvement can be difficult to differentiate from preeclampsia

Subglottic stenosis could complicate delivery; therefore, a consultation with an anesthesiologist is warranted before labor been described with some patients remaining dialysis-dependent or significant coronary
stenosis, aneurysms, or tailure 
Table 1 (continued)

\begin{tabular}{|c|c|c|c|c|c|}
\hline Type of vasculitis & References & Risk of vasculitis flare & Maternal outcomes & Fetal outcomes & Comments \\
\hline & & $\begin{array}{l}\text { Rare case reports } \\
\text { described disease onset } \\
\text { in postpartum } \\
\text { One maternal death } \\
\text { (second trimester) is } \\
\text { reported, but the } \\
\text { patient did not attend } \\
\text { follow-up visits after } \\
\text { initial improvement } \\
\text { with plasmapheresis } \\
\text { and glucocorticoids } \\
\text { One case report described } \\
\text { the recurrence of } \\
\text { anti-GBM disease in a } \\
\text { subsequent pregnancy }\end{array}$ & $\begin{array}{l}\text { undergoing renal } \\
\text { transplantation and } \\
\text { others returning to a } \\
\text { normal renal function } \\
\text { (less common) } \\
\text { None had permanent } \\
\text { pulmonary disease } \\
\text { Gestational diabetes: } 38 \% \\
\text { (all on glucocorticoids) } \\
\text { Preeclampsia: } 25 \% \\
\text { Cesarean deliveries: } 50 \%\end{array}$ & $\begin{array}{l}1 \text { fetus had severe } \\
\text { complications } \\
\text { associated with } \\
\text { prematurity (cerebral } \\
\text { hemorrhage) }\end{array}$ & \\
\hline $\begin{array}{l}\text { Cryoglobulinemic } \\
\text { vasculitis }\end{array}$ & $\begin{array}{l}{[2,5,} \\
\quad 45-47]\end{array}$ & $\begin{array}{l}\text { Diagnosis was made } \\
\text { before conception in } \\
\text { two-thirds of the } \\
\text { described cases } \\
2 \text { pregnancies with onset } \\
\text { of vasculitis during } \\
\text { pregnancy (palpable } \\
\text { macular rash and } \\
\text { hypertension, } \\
\text { glomerulonephritis) } \\
3 \text { vasculitis flares } \\
\text { occurred (mononeuritis } \\
\text { multiplex, skin } \\
\text { involvement, } \\
\text { hypertension with } \\
\text { proteinuria and } \\
\text { arthralgias) (50\%) } \\
\text { One case noted an } \\
\text { improvement in } \\
\text { vasculitis symptoms } \\
\text { during pregnancy }\end{array}$ & $\begin{array}{l}\text { Good maternal outcomes: } \\
4 / 6(67 \%) \\
\text { Preeclampsia described in } \\
\text { one pregnancy } \\
\text { One miscarriage because } \\
\text { of vasculitis flare }(1 / 6) \\
\text { Preterm delivery: } 1 / 5 \\
\text { (31 weeks) }(20 \%) \\
\text { Cesarean deliveries: } 3 / 5 \\
(60 \%)\end{array}$ & $\begin{array}{l}\text { LBW: } 1 / 5 \text { (premature) } \\
\text { One fetus (mother with } \\
\text { type } 1 \\
\text { cryoglobulinemia) had } \\
\text { transient cold-induced } \\
\text { cutaneous lesions } \\
\text { (resolved with } \\
\text { warming and clearance } \\
\text { of maternal IgG) }\end{array}$ & $\begin{array}{l}\text { Few cases described ( } 6 \\
\text { pregnancies) } \\
\text { Avoidance of cold } \\
\text { temperatures in } \\
\text { neonates and mothers } \\
\text { with cryoglobulinemia } \\
\text { is advised to avoid } \\
\text { precipitation of } \\
\text { cryoglobulins }\end{array}$ \\
\hline IgA vasculitis & $\begin{array}{l}{[2,7 \cdot \bullet, 22} \\
\quad 48 \cdot, 49 \\
50]\end{array}$ & $\begin{array}{l}\text { Disease onset during } \\
\text { pregnancy }(50-75 \%) \\
\text { or postpartum }(10 \%) \\
\text { has been reported } \\
\text { commonly in the } \\
\text { literature and is } \\
\text { associated with poorer } \\
\text { outcomes } \\
\text { No disease exacerbations } \\
\text { were observed in a } \\
\text { study of } 247 \\
\text { pregnancies. However, } \\
\text { case reports describe } \\
\text { occasional flares of } \\
\text { abdominal pain, } \\
\text { arthralgias, and } \\
\text { purpura. } \\
\text { Mild disease } \\
\text { exacerbations reported } \\
\text { in up to } 38 \%\end{array}$ & $\begin{array}{l}\text { Pregnancy outcomes are } \\
\text { usually good with no } \\
\text { maternal deaths } \\
\text { Increased risk of } \\
\text { spontaneous } \\
\text { miscarriages (1.9-fold), } \\
\text { preterm delivery } \\
\text { (2-fold), and } \\
\text { gestational } \\
\text { hypertension (4.7-fold) } \\
\text { Severe complications } \\
\text { rarely reported, such as } \\
\text { renal failure and } \\
\text { necrotizing ulcers } \\
\text { Renal complications } \\
\text { (mainly hypertension } \\
\text { and/or proteinuria) are } \\
\text { reported more } \\
\text { commonly in patients } \\
\text { affected by the disease } \\
\text { in their childhood. One } \\
\text { case of eclampsia is } \\
\text { reported } \\
\text { Cesarean deliveries: up to } \\
50 \%\end{array}$ & $\begin{array}{l}\text { No increase in stillbirth } \\
1 \text { fetal death occurred due } \\
\text { to rapidly progressive } \\
\text { renal failure in a patient } \\
\text { diagnosed during } \\
\text { pregnancy } \\
\text { LBW: } 15-25 \%\end{array}$ & $\begin{array}{l}\text { IgA are unable to cross } \\
\text { the placental barrier, } \\
\text { thus no neonatal cases } \\
\text { occurred }\end{array}$ \\
\hline
\end{tabular}


Table 1 (continued)

\begin{tabular}{|c|c|c|c|c|c|}
\hline Type of vasculitis & References & Risk of vasculitis flare & Maternal outcomes & Fetal outcomes & Comments \\
\hline $\begin{array}{l}\text { Hypocomplementemic } \\
\text { urticarial vasculitis } \\
\text { (anti-C1q vasculitis) }\end{array}$ & {$[51]$} & $\begin{array}{l}\text { Disease exacerbation: } 1 \\
\text { pregnancy }(1 / 3) \\
\text { Postpartum flare: } 1 / 3 \\
\quad \text { Variab }\end{array}$ & $\begin{array}{l}\text { No preeclampsia was } \\
\text { reported or other } \\
\text { complications } \\
\text { ble vessel vasculitis }\end{array}$ & No fetal complications & $\begin{array}{l}\text { Very few cases described } \\
\text { (3 pregnancies) }\end{array}$ \\
\hline Behçet's disease (BD) & $\begin{array}{c}{[2,5,52 \cdot \bullet} \\
53,54 \\
55 \bullet \bullet \\
56-59]\end{array}$ & $\begin{array}{l}\text { Improvements in the } \\
\text { disease reported in } \\
60 \% \text { of patients, } 30 \% \\
\text { worsened, and } 10 \% \\
\text { remained stable }\end{array}$ & $\begin{array}{l}\text { No clear association with } \\
\text { preeclampsia } \\
\text { Miscarriages range from } \\
7 \text { to } 25 \% \\
\text { Therapeutic abortions: } \\
\text { less than } 5 \% \\
\text { Increased preterm } \\
\text { deliveries (12-25\%) } \\
\text { and increased cesarean } \\
\text { deliveries } \\
\text { Increased } \\
\text { thromboembolic } \\
\text { events especially } \\
\text { postpartum }\end{array}$ & $\begin{array}{l}\text { No significant increases } \\
\text { in congenital } \\
\text { anomalies } \\
\text { Fetal deaths: less than } 3 \% \\
\text { LBW up to } 25 \%\end{array}$ & $\begin{array}{l}\text { Transient neonatal } \\
\text { Behçet's disease } \\
\text { described in a few } \\
\text { cases }\end{array}$ \\
\hline Cogan's syndrome (CS) & $\begin{array}{r}{[2,5,37} \\
60-64]\end{array}$ & $\begin{array}{l}\text { Vasculitis was diagnosed } \\
\text { before conception in all } \\
\text { patients } \\
\text { Vasculitis flare: } 3 \\
\text { pregnancies (interstitial } \\
\text { keratitis) }(33 \%) \\
\text { Slight improvement in } \\
\text { symptoms: } 2(22 \%) \\
\text { Vasculitis remained } \\
\text { stable: } 3(33 \%)\end{array}$ & $\begin{array}{l}\text { No complications seen } \\
\text { during pregnancy } \\
\text { Cesarean deliveries: } 4 / 9 \\
(44 \%) \\
\text { No preterm deliveries }\end{array}$ & $\begin{array}{l}\text { No perinatal } \\
\text { complications } \\
1 \text { neonate with LBW } \\
(1 / 8)\end{array}$ & $\begin{array}{l}\text { Few cases described }(<9 \\
\text { case reports) } \\
2 \text { case reports before } 1976 \\
\text { reported thoracic aorta } \\
\text { involvement in } \\
\text { pregnancy and aortic } \\
\text { insufficiency }\end{array}$ \\
\hline \multicolumn{6}{|c|}{ Single-organ vasculitis } \\
\hline $\begin{array}{l}\text { Cutaneous } \\
\text { leukocytoclastic } \\
\text { angiitis and cutaneous } \\
\text { arteritis }\end{array}$ & $\begin{array}{c}{[5,51,65,} \\
66]\end{array}$ & $\begin{array}{l}\text { Case reports described } \\
\text { occasional flares } \\
\text { limited to the skin }\end{array}$ & $\begin{array}{l}\text { Favorable outcomes } \\
\text { No severe maternal } \\
\text { morbidity reported } \\
\text { In a series of } 24 \\
\text { pregnancies: } \\
\text { Gestational hypertension: } \\
8 \% \\
\text { Preterm deliveries: } 13 \% \\
\text { Cesarean deliveries: } 38 \% \\
\text { ( } 25 \% \text { elective) }\end{array}$ & $\begin{array}{l}\text { Good fetal outcomes } \\
\text { LBW: none reported in a } \\
\text { series of } 24 \\
\text { pregnancies } \\
\text { Compared with the } \\
\text { general population, } \\
\text { admissions to neonatal } \\
\text { intensive care unit and } \\
\text { severe neonatal } \\
\text { morbidity not } \\
\text { increased (17 and } 4 \% \text {, } \\
\text { respectively) }\end{array}$ & $\begin{array}{l}\text { Cases of leukocytoclastic } \\
\text { vasculitis induced by } \\
\text { Ritodrine in pregnancy } \\
\text { have been reported }\end{array}$ \\
\hline Isolated aortitis & {$[5]$} & N/A & N/A & N/A & $\begin{array}{l}\text { No cases found of } \\
\text { isolated aortitis in } \\
\text { pregnancy. Aortic } \\
\text { involvement in } \\
\text { pregnancy is mostly } \\
\text { caused by TAK, and } \\
\text { rarely reported with } \\
\text { Cogan's syndrome or } \\
\text { rheumatoid arthritis }\end{array}$ \\
\hline $\begin{array}{l}\text { Primary central nervous } \\
\text { system vasculitis }\end{array}$ & $\begin{array}{l}{[5,7 \bullet \bullet, 22} \\
51]\end{array}$ & $\begin{array}{l}\text { Case reports of disease } \\
\text { onset during pregnancy } \\
\text { or postpartum are } \\
\text { reported } \\
\text { A recent study of } 4 \\
\text { pregnancies with CNS } \\
\text { vasculitis showed no } \\
\text { disease flare }\end{array}$ & $\begin{array}{l}\text { No complications } \\
\text { reported in these } 4 \\
\text { patients (no } \\
\text { miscarriages or } \\
\text { preeclampsia) } \\
\text { Preterm deliveries: } 25 \% \\
\quad(1 / 4) \\
\text { Mean gestational age: } \\
\quad 37.4 \text { weeks }\end{array}$ & $\begin{array}{l}\text { No stillbirths or fetal } \\
\text { growth restrictions } \\
\text { were documented. }\end{array}$ & $\begin{array}{l}\text { Rare cases }(<10) \\
\text { Reversible cerebral } \\
\text { vasoconstriction } \\
\text { syndrome is frequently } \\
\text { misdiagnosed as } \\
\text { primary cerebral } \\
\text { vasculitis }\end{array}$ \\
\hline
\end{tabular}


Table 1 (continued)

\begin{tabular}{|c|c|c|c|c|}
\hline Type of vasculitis & References Risk of vasculitis flare & Maternal outcomes & Fetal outcomes & Comments \\
\hline & & $\begin{array}{l}\text { Cesarean deliveries: } \\
(2 / 4) \text { for obstetric } \\
\text { indications }\end{array}$ & & \\
\hline
\end{tabular}

LBW, low birth weight; IUGR, intrauterine growth restriction

\section{General Principles}

More than a thousand pregnancies have been reported in patients with systemic vasculitides, mostly consisting of case reports and small observational series. To our knowledge, the only prospective observational study on vasculitis and pregnancy comes from the Vasculitis Pregnancy Registry (VPreg) imbedded within the Vasculitis Patient-Powered Research Network (VPPRN) [9•].

\section{Interaction of Pregnancy and Vasculitis}

It is crucial to discuss conception with vasculitis patients, as maternal and obstetrical complications are influenced by disease activity and prior organ damage [5, 8]. Ideally, patients should have minimal disease activity at least 6 months prior to conception and should be on stable and pregnancy-compatible medications $[4,5]$.

Close monitoring of pregnant patients with vasculitis is warranted. Follow-up parameters may be altered in pregnancy. Serum C-reactive protein (CRP) levels are normally elevated in pregnancy with the highest values seen during labor [10]. Diagnostic imaging should not be withheld in pregnant women if clinically indicated, although caution is recommended, especially with the use of gadolinium contrast, on account of recent data suggesting an association with an increased risk of neonatal deaths and stillbirths [11, 12].

\section{Effect of Vasculitis on Pregnancy in General}

Favorable pregnancy outcomes can be achieved in patients with systemic vasculitides especially when the disease is in remission and conception is carefully planned [3•]. Maternal age for women with vasculitides appears to be higher than in other healthy women, on average 5 years older, and can have an additional impact on pregnancy outcomes [13].

Hypertension is reported in up to $20 \%$ of these pregnancies $[5,65]$. However, higher rates of hypertension and preeclampsia are observed in patients with TAK $[3 \bullet, 7 \bullet \bullet]$. In most studies, gestational diabetes does not have a higher prevalence when compared with the general population and mostly affects patients taking glucocorticoids [37, 65].
The rate of pregnancy loss is higher in women with vasculitides (mostly BD, TAK, small-vessel vasculitis). It has been reported to be as high as $34 \%$ in a study of 74 pregnancies, while the expected rate of miscarriages in the United States is estimated at 15-20\% [13]. Most studies also showed an increase in fetal loss rate $[21,51,65]$, although one study on 55 pregnancies did not find a significant increase in miscarriages when compared with the general population [37].

Increased vasculitis activity is associated with preterm delivery, which has an incidence of 20-53\%, compared with $13 \%$ in the general population $[7 \cdot, 13,21,37,51,65]$. There are no reported major congenital malformations in relation to vasculitis [37].

Low birth weight (LBW) is reported in $10 \%$ of pregnancies, which is slightly increased compared with the general population, with increased admission into the neonatal intensive care unit $[37,65]$. A study reported similar findings with increased LBW being mostly attributed to preterm delivery [51]. Intrauterine growth restriction (IUGR) is more frequent in pregnant women with small-vessel vasculitis, up to $30 \%[7 \bullet \cdot]$.

Cesarean deliveries are more frequently performed, in up to half of pregnancies, mainly for obstetrical reasons, such as IUGR, prolonged labor, or non-reassuring fetal heart rate $[7 \bullet \bullet, 21,65]$. However, induction for concerns of the underlying disease occurs in about $40 \%$ of cases according to a study [37].

\section{Effect of Pregnancy on Vasculitis in General}

Pregnancy is not recognized as a trigger for the development of vasculitis. However, there are descriptions of vasculitis diagnosed in pregnancy, postpartum, or post-abortion, especially PAN, AAV, and IgA vasculitis [6]. PAN and microscopic polyangiitis (MPA) have worst prognoses when diagnosed during pregnancy [5]. Pregnancy outcomes in a patient with vasculitis do not predict future outcomes in subsequent pregnancies $[6,22]$.

The prospective V-Preg registry of pregnancies in women with vasculitides has enrolled 62 patients between 2015 and 2018 , mostly with TAK or granulomatosis with polyangiitis (GPA), and is still recruiting. Results of these first patients were presented as an abstract, and data on the first trimester showed that $75 \%$ of patients self-reported minimal or absent 
disease activity and no fetal loss was reported. Vasculitis was also well controlled before conception with no hospitalization three months prior. Women with pregnancies prior to the vasculitis diagnosis had a high rate of miscarriages (44\%) [9•].

Disease flares are higher in patients with active or recently diagnosed vasculitis, with a subsequent increased risk of preterm deliveries and miscarriages [7••]. Flares are reported in 20 to $40 \%$ of pregnancies [7•, 13, 21, 37, 51]. Ultimately, the risk of exacerbation seems low, but is variable depending on the type of vasculitis. A Canadian study found that exacerbations were more often seen with retinal and small-vessel vasculitis $\left[7^{\bullet \bullet}\right]$. Another study on necrotizing vasculitis found that $50 \%$ of patients had mild to moderate flares and up to $20 \%$ had severe complications [21]. On the opposite, improvement in disease activity during pregnancy can occur in patients with non-severe BD [5].

Maternal deaths, mostly from disease exacerbations, are rare but have been reported, mostly with TAK, PAN, and AAV [5]. Some authors suggest avoiding pregnancy in patients with severe renal impairment, cardiac insufficiency, uncontrolled asthma in eosinophilic granulomatosis with polyangiitis (EGPA), severe pulmonary hypertension, and uncontrolled hypertension with renal involvement [5].

Patients should be advised to continue their medications and have regular follow-ups in the postpartum period (3 months) because flares have been reported in $20-40 \%$ of patients [37, 51]. Postpartum flares may be more frequent in patients with $\mathrm{BD}$ and are reported in $30 \%$ of patients [37].

\section{Treatment Considerations}

Among the medications commonly used in the treatment of systemic vasculitis, methotrexate, mycophenolate mofetil, and cyclophosphamide have recognized teratogenic effects and should be stopped prior to conception, in accordance with published guidelines. However, cyclophosphamide can be considered during the second or third trimester for life- or organ-threatening complications. Leflunomide also shows detrimental effects on the fetus and should be stopped 24 months prior to conception or a cholestyramine washout should be done [67••]. Azathioprine, IVIg, hydroxychloroquine, colchicine, cyclosporine, and tacrolimus appear to be compatible with pregnancy $[67 \bullet \bullet]$.

Glucocorticoids are cornerstones for the treatment of vasculitis. Although earlier studies reported an association with fetal malformations, especially orofacial clefts, recent studies, including a large Danish cohort study, have shown no association between glucocorticoids use and orofacial clefts [68]. Oral prednisone transplacental absorption is low, but prolonged use may be associated with an increased risk of preterm deliveries and IUGR, as well as maternal hypertension and gestational diabetes $[3 \bullet]$.
Concerns have been expressed regarding congenital anomalies related to the use of biologics, with reports showing an increased risk of $30 \%$. A meta-analysis, including only one study with vasculitis patients (BD) and mostly on tumor necrosis factor (TNF) inhibitors or anti-B cell (rituximab), reported that this association is no longer significant when adjusted for disease activity and showed similar results for preterm deliveries. There was a $68 \%$ increased risk of having LBW babies when exposed to biologics, but no increased risk of serious infection in neonates during their first year of life [69••]. Evidence on TNF inhibitors mostly comes from inflammatory bowel disease, and patients on these medications have shown favorable pregnancy outcomes [3•]. However, infants born to mothers exposed to anti-TNF should not receive live vaccines for the first 6 months of life. Unlike other TNF inhibitors, certolizumab has limited placental transfer and fetal exposure [67••]. Rituximab should be continued during pregnancy. However, it crosses the placenta and has been associated with $\mathrm{B}$ cell depletion in the neonates sometimes persisting for months $[3 \bullet, 70]$.

The prophylactic use of aspirin during pregnancy has been associated with a $62 \%$ reduction in preterm preeclampsia in women at high risk, including chronic hypertension [71]. A meta-analysis showed similar results when aspirin was initiated before 16 weeks of gestation and at a dose of $\geq 100 \mathrm{mg}$ [72]. Aspirin has also been associated with a reduction in IUGR [73]. However, the role of aspirin in pregnant women with vasculitides is not established. There are no studies assessing the potential reduction of preeclampsia in these patients. Because of the increased risk of preeclampsia in patients with vasculitides (especially TAK), many experts advocate the prescription of aspirin, especially in the case of preexisting hypertension or chronic kidney disease [5, 51].

\section{Behçet's Disease}

$\mathrm{BD}$ is one of the most common reported vasculitis in pregnancy [5]. In the United States, the overall prevalence of deliveries from mothers with BD is 1.4 per 100,000 and has been increasing in the past 15 years $[52 \bullet \bullet]$.

\section{Effects of BD on Pregnancy}

Numerous studies have evaluated the effects of BD on pregnancy with discrepancies in the rate of pregnancy-related complications. One possible explanation is the broad spectrum of clinical manifestations with variable disease severity in different cultural and geographic areas $[22,53]$. However, most pregnancies in BD have good outcomes.

Obstetric complications, mostly miscarriages, are increased by 7 -fold in pregnancies with $\mathrm{BD}$ in patients with prior thromboembolic events [54]. An increase in pregnancy 
complications (hypertension, gestational diabetes, preterm labor, and vascular events) after the diagnosis of BD is also reported, when compared with pregnancies before the diagnosis of $\mathrm{BD}$ [53].

There is no clear association between $\mathrm{BD}$ and preeclampsia $[55 \bullet \cdot, 56,57,74,75]$. Hypertension and preeclampsia have been reported in 1 to $6 \%$ of pregnancies with $\mathrm{BD}[2,52 \bullet, 53$, 54]. The prevalence of gestational diabetes does not seem to be higher in these patients $[52 \cdot \bullet]$.

Preterm delivery was seen in only $1 \%$ of BD pregnancies [2] and with an increased risk of up to 2 times in recent studies $[52 \bullet \bullet, 65]$. Other data support the increase in preterm labor with an estimated rate of $12-25 \%$ [55••, 56, 57].

Only a few studies have suggested an increase in fetal losses [53, 57]. A meta-analysis reported an incidence of miscarriages of $9 \%$, whereas it ranged in more recent studies from 7 to $30 \%$, with fetal deaths up to $3 \%[2,53,54,55 \bullet \cdot, 56,57]$. It was suggested that the increase in miscarriages resulted from a vascular complication of the decidua interfering with normal implantation [53]. These data contrast with results of other studies that did not show an increased risk of miscarriage $[54,58,59,75]$.

LBW is reported in a few studies, in up to $25 \%$ of pregnancies in some recent ones, as opposed to an incidence of $8 \%$ in the general population in the United States [55••, 57, 76]. However, several studies did not find an increased risk [53, $54,56,65]$.

Most studies have not reported an increase in cesarean deliveries, but a few noted an incidence of up to $42 \%$ of deliveries, mostly for obstetrical reasons (not vasculitisrelated) $[52 \bullet \cdot, 56]$.

\section{Effects of Pregnancy on BD}

The disease course seems variable with many studies reporting that remission is frequent during pregnancy [53, $54,55 \bullet \cdot, 58,59,77]$, whereas others suggested that flares are more common [74, 75, 78, 79].

In a meta-analysis, $\mathrm{BD}$ was reported to flare up during pregnancy in about $30 \%$ of cases, with manifestations mostly consisting of ulcers (58\%), erythema nodosum, arthritis, and lastly, ocular involvement, mostly in the postpartum period $[2$, $54,77,80]$. Most flares occurred in the first trimester, but one study found them to predominate in the third trimester [74, 80]. Exacerbation rates are reported between 8 and $66 \%$ in the literature $[53,54,55 \bullet \bullet, 56,58,59,74,75,80]$.

On average, the disease remains stable in about $10 \%$ of patients, whereas $60 \%$ improve during pregnancy [2]. A French study reported an annual vasculitis flare rate 3 times lower in pregnancy [54]. Another study concluded that there is a 5-fold increase chance of remission in pregnancy and 4-fold in postpartum [53]. Improvement has been linked to hormonal changes during pregnancy with progesterone inhibiting the function of macrophages and lymphocytes and estrogen promoting the synthesis of anti-inflammatory cytokines and suppressing interleukin 12 (IL12) production $[52 \bullet \bullet, 55 \bullet$ ] However, patients should still be closely monitored in the postpartum period, because a few studies have reported frequent flares after delivery [37].

Only one maternal death has been reported in a 45 -year-old patient with a colonic perforation secondary to intestinal ulcers at 6 weeks of gestation [52••].

Thromboembolic events are reported in 10 to $37 \%$ of affected BD patients in general [81]. Pregnancy also increases the daily risk of venous thromboembolic events by 10 -fold peripartum and up to 35-fold postpartum [82]. In examining 144 pregnancies with $\mathrm{BD}$, thromboembolic events were increased by 15 times in the postpartum period [52・•]. Vascular complications were also more common in a study of 63 pregnancies with $\mathrm{BD}$ [56]. Rare vascular complications in pregnancies with $\mathrm{BD}$ are reported, such as cerebral venous thrombosis, superior vena cava thrombosis, intracardiac thrombosis, Budd-Chiari syndrome, ovarian vein thrombosis, deep vein thrombosis, and pulmonary embolism $[52 \bullet \bullet, 56,58$, 83]. Given this heightened risk, patients should be closely monitored for thromboembolic events, especially in the postpartum period. The role of routine thromboprophylaxis is not established.

\section{Treatment Considerations}

Several therapies can be used for $\mathrm{BD}$, including colchicine, short courses of glucocorticoids, and anti-TNF for the most severe cases. A recent meta-analysis reported no increase in major fetal malformations or fetal loss when using colchicine during pregnancy. However, its use was associated with LBW and prematurity when indications were not limited to familial Mediterranean fever [84*0]. Even though placental transfer occurs, colchicine appears to be compatible with pregnancy and even protective in $\mathrm{BD}$ with a decrease in flare by two-fold in a study [54].

Anti-TNF has been used in BD without an increase in congenital anomalies [85]. Cyclosporine can be used during pregnancy, but blood pressure monitoring is warranted [67••]. Apremilast, an oral phosphodiesterase-4 inhibitor, has recently shown promising results in the reduction of oral ulcers [86]. However, there is no evidence on its safety during pregnancy and it cannot be recommended at this time [67••].

\section{Anesthetic Considerations}

It has been feared that scarring and nodule formation could develop at the site of neuraxial anesthesia in BD patients. Although the literature is scarce, there is no evidence to suggest avoiding regional anesthesia. Concerns about airway management have been expressed in patients with $\mathrm{BD}$ related 
to oropharyngeal scarring and the possible worsening of ulcerations upon manipulation. However, no complicated intubations are reported even in severe disease [87]. An assessment with an anesthesiologist is suggested to guide the decision process.

\section{Neonatal Behçet}

A small number of case reports describe transient neonatal BD mostly consisting of oral or genital ulcerations and skin findings that resolve up to 8 weeks after birth $[83,88,89]$. One neonatal death occurred from respiratory distress and neurological involvement following delivery at 34 weeks of gestation and another neonate, born at 38 weeks, suffered lifethreatening complications a few days postpartum treated with glucocorticoids [90, 91]. Most cases were reported in mothers who suffered from BD before pregnancy and had orogenital ulcerations during pregnancy [89]. It has been hypothesized that the disease could be mediated by a transplacental transfer of maternal antibodies [83]. Necrotizing villitis and decidual vasculitis have been identified in two placentas of patients affected with $\mathrm{BD}$, one pregnancy occurred with good maternal and fetal outcomes and the other one resulted in a therapeutic abortion because of colchicine exposure [92].

\section{Takayasu Arteritis}

\section{Effects of TAK on Pregnancy}

Most pregnancies result in good maternal and obstetrical outcomes. Patients should be advised not to conceive until blood pressure is well controlled with pregnancy-safe medications, as better pregnancy outcomes are reported with normal blood pressure in the preconception period [93]. A higher incidence of complications is reported in patients with severe disease, pre-existing hypertension, and a greater number of previously damaged vessels $[15 \bullet, 16,17 \bullet \bullet]$. Patients of African descent could have a higher incidence of pregnancy-related complications [18].

One retrospective study in Brazil evaluated complications in pregnant women before TAK diagnosis. They found an incidence of hypertension about 7 times higher in the group pre-diagnosis compared with healthy controls [19]. However, other studies did not observe this trend in pregnancies before TAK diagnosis [18].

Exacerbation of pre-existing arterial hypertension and preeclampsia are the most common complications associated with TAK in pregnancy [2, 15•, 18, 19, 94]. Infradiaphragmatic artery involvement, especially renal artery stenosis, appears to be a major risk factor in most studies [15•, $16,17 \bullet \bullet, 20,94,95]$. Stenosis of the renal arteries leads to an increase in renin production and subsequently to an increase in blood pressure and uteroplacental insufficiency resulting in IUGR $[17 \bullet \bullet, 20 \bullet, 96 \bullet, 97]$. However, a French cohort of 98 pregnancies did not find renal artery involvement to be associated with preeclampsia and IUGR [18].

Hypertension and preeclampsia affect $20-40 \%$ of pregnancies with TAK, as compared with $2-8 \%$ in the general population [17••, 98]. Consistent findings have been reported by other authors $[2,15 \bullet, 20 \bullet, 96 \bullet, 99]$. The overall rates of hypertension and preeclampsia reported are variable among studies and are being reported in up to 100 and $75 \%$ of pregnancies, respectively, with the highest rate among Indian patients $[17 \cdot \bullet, 100]$. Careful monitoring and aggressive management of hypertension should be sought.

Angioplasty for renal artery stenosis in the preconception period could have a protective role during pregnancy based on a small number of patients who had uneventful pregnancies after this intervention [95].

LBW and IUGR are the most common complications reported in newborns. In a literature review of more than 400 pregnancies, the occurrence of LBW and IUGR was $20 \%$ with a range previously reported between 4 and $52 \%$. The highest incidence was associated with bilateral renal involvement $[17 \bullet \bullet, 18,100,101]$.

A recent study noted that preterm deliveries occur in $17 \%$ of patients with ranges in the literature between 4 and $30 \%$ and fetal loss between 8 and 30\% [15•, 16, 17••, 93, 96•]. Intrauterine fetal deaths were reported in $4-5 \%$ in TAK patients, as compared with $1-2 \%$ in the general population $[2$, $17 \bullet \bullet, 18,99]$.

With regard to labor, $35-50 \%$ of pregnancies in TAK patients had a cesarean delivery $[2,17 \bullet \bullet, 96 \bullet]$. Induction of labor was performed in multiple reports for severe hypertension, IUGR, retinopathy, aortic insufficiency, aortic aneurysms, or severe vasculitis [2].

\section{Effects of Pregnancy on TAK}

Physiological changes of pregnancy do not seem to affect disease activity $[2,96 \cdot, 102]$. A meta-analysis found that exacerbation rates are reported in 3\% of pregnancies with TAK [2]. More recent evidence noted an incidence of vasculitis flare in up to $25 \%$ of pregnancies $[7 \bullet \bullet, 15 \bullet$. Active disease during pregnancy has been associated with life-threatening complications in more than $5 \%$ of pregnancies and a 13 -fold increase of the risk of obstetric complications, such as preeclampsia, miscarriages, IUGR, and preterm births $[17 \bullet \bullet, 18$, $20 \bullet, 103 \cdot \bullet$. However, a few series suggested improvement of the disease during pregnancy $[18,19,102]$. A study showed that CRP levels and digital plethysmography improved during pregnancy, and up to one year after delivery [102].

Increased circulating blood volume and cardiac load during pregnancy can lead to a deterioration of pre-existing vascular lesions [15•]. Rare cases of aortic insufficiency, myocardial 
infarction, renal insufficiency, retinopathy, congestive heart failure, aneurysm formation, and stroke have been reported, as well as aortic dissection $\left[2,19,20^{\bullet}\right]$.

At least two maternal deaths were reported in the literature resulting from myocardial infarction in the postpartum period and uncontrolled hypertension leading to heart failure, encephalopathy, and renal insufficiency $[2,16,18]$.

\section{Disease Control and Treatment Considerations}

Patients receiving treatments for TAK during pregnancy seem to have lower complication rates $[18,93]$. A recent study observed lower rates of preeclampsia in patients receiving glucocorticoids but did not find the same outcomes with aspirin [17••]. Aspirin should particularly be considered during pregnancy in TAK because of the higher risk of preeclampsia and IUGR. Antibiotic prophylaxis to prevent infective endocarditis is recommended during delivery in patients with aortic insufficiency $[2,5,8]$.

\section{Anesthetic Considerations and Labor Management}

Regional anesthesia has been advocated for labor in TAK patients and usually allows greater hemodynamic stability as well as evaluation of cerebral perfusion. A more profound decrease in preload can be observed with spinal anesthesia; therefore, concern has been expressed of a greater risk of ischemic complications, such as cerebral ischemia. However, many case reports have noted successful outcomes in patients with spinal blocks or combined spinal-epidural anesthesia [5].

Many authors have suggested to shorten the active phase of the second stage of labor because of a possible significant increase in blood pressure and therefore an increased risk of cerebral hemorrhage and congestive heart failure $[8,22,104]$. Blood pressure monitoring during labor is of paramount importance and blood pressure discrepancies between upper and lower extremities should be noted beforehand. Patients should also be closely monitored during the first $24-48 \mathrm{~h}$ after delivery [2]. A consultation with the anesthesiology team should be sought at an early stage in pregnancy to plan labor and hemodynamic monitoring.

\section{ANCA-Associated Vasculitis}

AAV vasculitis is a group of necrotizing vasculitides, including granulomatosis with polyangiitis (GPA), eosinophilic granulomatosis with polyangiitis (EGPA), and microscopic polyangiitis (MPA) [1]. These diseases are most often seen in subjects in their 50s, but women of child-bearing age can also be affected. There is a growing literature about pregnancy outcomes in these patients. AAV may be the most frequently diagnosed vasculitis during pregnancy, mostly prior to the third trimester $[3 \bullet, 105 \bullet \cdot$.
In a study of 110 patients with AAV, the diagnosis was made before conception in $63 \%$, during pregnancy in $29 \%$, and in the postpartum period in $8 \%$ of patients. Disease flares occurred in $15 \%$ of pregnancies $[106 \bullet \cdot]$.

\section{Effect of AAV on Pregnancy}

Pregnancy outcomes are reportedly often favorable in patients with AAV. Complications are more frequent when the disease is active at conception or develops during pregnancy and in patients with severe major organ damage from previous flares (renal insufficiency, cardiomyopathy) $[3,5,8,105 \cdot 0]$.

A systematic review observed that $20 \%$ of pregnancies were delivered preterm and $2 \%$ resulted in stillbirths [106•*]. Preterm birth is one of the most common complications associated with $\mathrm{AAV}$, with an incidence range previously reported of $25-50 \%$, mostly in GPA [2, 7••, 21, 37]. A recent study with vasculitis diagnosed during pregnancy showed a preterm birth rate of $73 \%$, whereas two studies, including patients with disease in remission, only showed a rate of $7-9 \%[34,105 \bullet \cdot, 107]$.

Spontaneous miscarriages have a variable incidence, between 4 and $20 \%$ of pregnancies $[2,21,34,105 \bullet \cdot, 106 \bullet$, 107]. However, one recent Canadian study in 20 pregnancies with AAV reported no miscarriages [7••].

LBW occurred in $10-30 \%$ of pregnancies $[5,7 \cdot \bullet, 105 \bullet \bullet$, $106 \bullet \cdot$. A case series describing patients in remission prior to conception reported no fetal growth restriction [107].

Hypertension and preeclampsia were noted in $10-30 \%$ of AAV pregnancies $[2,7 \bullet \bullet, 34,105 \bullet \bullet, 106 \bullet \cdot]$. Other complications reported with AAV are placenta previa with antepartum hemorrhage, retroplacental hematoma, and premature rupture of membranes $[2,3 \cdot, 6,21]$.

Like with other vasculitides, cesarean deliveries are more commonly performed, in around $50 \%$ of cases, mostly for obstetrical indications, such as arrest of descent and fetal distress $[2,7 \bullet \bullet, 21,105 \bullet \bullet, 106 \bullet \bullet]$. Regional anesthesia is preferred in patients with subglottic stenosis and counseling should be sought with an anesthesiologist [108].

\section{Effect of Pregnancy on AAV}

AAV activity does not seem to be majorly affected by pregnancy. Exacerbations are more commonly associated with severe disease and have been noted in $35 \%$ of patients in a recent study, although most often they were non-severe $[3 \cdot, 7 \cdot \bullet]$. Other studies have reported flares in about $20-50 \%$ of cases with the highest risk in the first and second trimesters and in the first month postpartum $[5,8,13,105 \cdot \bullet]$.

Life-threatening complications affected $20 \%$ of pregnancies in a study on 20 pregnancies with necrotizing vasculitides [21]. Maternal complications consisted of alveolar hemorrhage, respiratory failure, transient ischemic attacks, severe cardiac failure, renal insufficiency, limb ischemia, and 
exacerbation of bronchial or subglottic stenosis [105••]. Asthma decompensation and/or cardiac failure complicate $25-50 \%$ of pregnancies with EGPA with a poor prognosis associated with cardiac involvement $[2,21]$. There are few reported maternal deaths, all prior to $2002[35,105 \bullet \bullet, 106 \bullet \bullet$.

Placental transfer of anti-MPO antibodies has been reported in the literature with only one case of neonate, delivered at 33 weeks of gestation, developing pulmonary hemorrhage and renal failure $[3 \cdot, 22,32]$.

\section{Conclusion}

Pregnancies in women with systemic vasculitides should be considered high risk. Favorable maternal and fetal outcomes are reported, especially when the pregnancy is planned, and the disease is in sustained remission. Patients should be closely monitored as life-threatening complications have been described, mostly when cardiac or renal systems are involved. The number of published articles on the subject has increased tremendously in the past years, thereby improving our knowledge on the overall risk associated with pregnancy in vasculitis. However, more data from prospective registries remain needed to better evaluate pregnancy outcomes and identify best predictors and treatment options of disease flares. The role of aspirin in the prevention of preeclampsia in patients with systemic vasculitides should also be further investigated, to help clinicians in the management and monitoring of these patients.

\section{Compliance With Ethical Standards}

Conflict of Interest CP reports receiving fees for serving on advisory boards from Chemocentryx, GlaxoSmithKline, Sanofi, and Hoffman-La Roche; he also reports lecture fees and research grant support from Hoffman-La Roche and GlaxoSmithKline. RD reports receiving speaking honoraria and grant funding for projects on labor induction and coronavirus infections in pregnancy, unrelated to this publication. No other conflicts of interest are declared.

Human and Animal Rights and Informed Consent This article contains studies on humans exclusively and review articles performed by some of the listed authors. These studies have been previously published and complied with the ethical standards required.

\section{References}

Papers of particular interest, published recently, have been highlighted as:

- Of importance

•- Of major importance

1. Jennette JC. Overview of the 2012 revised International Chapel Hill Consensus Conference nomenclature of vasculitides. Clin
Exp Nephrol. 2013;17(5):603-6. https://doi.org/10.1007/s10157013-0869-6.

2. Gatto M, Iaccarino L, Canova M, Zen M, Nalotto L, Ramonda R, et al. Pregnancy and vasculitis: a systematic review of the literature. Autoimmun Rev. 2012;11(6-7):A447-59. https://doi.org/10. 1016/j.autrev.2011.11.019.

3. Machen L, Clowse ME. Vasculitis and pregnancy. Rheum Dis Clin N Am. 2017;43(2):239-47. https://doi.org/10.1016/j.rdc. 2016.12.005 This article summarizes the literature on pregnancy outcomes in patients with AAV, PAN, TAK and BD.

4. Doria A, Bajocchi G, Tonon M, Salvarani C. Pre-pregnancy counselling of patients with vasculitis. Rheumatology (Oxford). 2008;47(Suppl 3):iii13-5. https://doi.org/10.1093/rheumatology/ ken 152.

5. Pagnoux C, Mahendira D, Laskin CA. Fertility and pregnancy in vasculitis. Best Pract Res Clin Rheumatol. 2013;27(1):79-94. https://doi.org/10.1016/j.berh.2013.02.002.

6. Pagnoux C. Pregnancy and vasculitides. Presse Med. 2008;37(11):1657-65. https://doi.org/10.1016/j.lpm.2008.06. 016.

7.• Nguyen V, Wuebbolt D, Pagnoux C, D'Souza R. Pregnancy outcomes in women with primary systemic vasculitis: a retrospective study. J Matern Fetal Neonatal Med. 2019:1-7. https://doi.org/10. $1080 / 14767058.2019 .1671329$ This Canadian study is a retrospective study of pregnancy outcomes in patients with primary vasculitides distinguished by vasculitis type.

8. Langford CA, Kerr GS. Pregnancy in vasculitis. Curr Opin Rheumatol. 2002;14(1):36-41. https://doi.org/10.1097/ 00002281-200201000-00007.

9. Golenbiewski J, Young K, Burroughs C, Kullman J, Merkel P, Clowse M. The Vasculitis Pregnancy Registry (VPREG): baseline information for the first 3 years. Abstract presented at the American College of Rheumatology annual meeting in Atlanta, Georgia November 2019. 2019. Ongoing prospective international registry on pregnancy outcomes in women with vasculitis.

10. Watts DH, Krohn MA, Wener MH, Eschenbach DA. C-reactive protein in normal pregnancy. Obstet Gynecol. 1991;77(2):17680. https://doi.org/10.1097/00006250-199102000-00002.

11. Ray JG, Vermeulen MJ, Bharatha A, Montanera WJ, Park AL. Association between MRI exposure during pregnancy and fetal and childhood outcomes. JAMA. 2016;316(9):952-61. https:// doi.org/10.1001/jama.2016.12126.

12. Committee on Obstetric P. Committee opinion no. 723: guidelines for diagnostic imaging during pregnancy and lactation. Obstet Gynecol. 2017;130(4):e210-e6. https://doi.org/10.1097/AOG. 0000000000002355 .

13. Clowse ME, Richeson RL, Pieper C, Merkel PA, Vasculitis Clinical Research C. Pregnancy outcomes among patients with vasculitis. Arthritis Care Res (Hoboken). 2013;65(8):1370-4. https://doi.org/10.1002/acr.21983.

14. Duhaut P, Abert MC, Le Page L, Bosshard S, Grunenberger F, Goichot B, et al. Giant cell arteritis and polymyalgia rheumatica: influence of past pregnancies? The GRACG multicenter case control study. Rev Med Interne. 2004;25(11):792-800. https://doi. org/10.1016/j.revmed.2004.07.011.

15. Tanacan A, Unal C, Yucesoy HM, Duru SA, Beksac MS. Management and evaluation of pregnant women with Takayasu arteritis. Arch Gynecol Obstet. 2019;299(1):79-88. https://doi. org/10.1007/s00404-018-4927-x Retrospective study of 22 pregnancies in TAK and their pregnancy outcomes.

16. Suri V, Aggarwal N, Keepanasseril A, Chopra S, Vijayvergiya R, Jain S. Pregnancy and Takayasu arteritis: a single centre experience from North India. J Obstet Gynaecol Res. 2010;36(3):519 24. https://doi.org/10.1111/j.1447-0756.2010.01226.x. 
17.• Abisror N, Mekinian A, Hachulla E, Lambert M, Morel N, Chapelon C, et al. Analysis of risk factors for complications and adverse obstetrical outcomes in women with Takayasu arteritis: a French retrospective study and literature review. Clin Rheumatol. 2020. https://doi.org/10.1007/s10067-020-05024-4 A French study of 43 pregnancies in TAK evaluating the risk factors for complications nd pregnacy outcomes; largest literature review on the subject.

18. Comarmond C, Mirault T, Biard L, Nizard J, Lambert M, Wechsler B, et al. Takayasu arteritis and pregnancy. Arthritis Rheumatol. 2015;67(12):3262-9. https://doi.org/10.1002/art. 39335.

19. Assad AP, da Silva TF, Bonfa E, Pereira RM. Maternal and neonatal outcomes in 89 patients with Takayasu arteritis (TA): comparison before and after the TA diagnosis. J Rheumatol. 2015;42(10):1861-4. https://doi.org/10.3899/jrheum.150030.

20. David LS, Beck MM, Kumar M, Rajan SJ, Danda D, Vijayaselvi R. Obstetric and perinatal outcomes in pregnant women with Takayasu's arteritis: single centre experience over five years. J Turk Ger Gynecol Assoc. 2020;21(1):15-23. https://doi.org/10. 4274/jtgga.galenos.2019.2019.0115 This Turkish study evaluated pregnancy outcomes in 16 pregnancies with TAK.

21. Pagnoux C, Le Guern V, Goffinet F, Diot E, Limal N, Pannier E, et al. Pregnancies in systemic necrotizing vasculitides: report on 12 women and their 20 pregnancies. Rheumatology (Oxford). 2011;50(5):953-61. https://doi.org/10.1093/rheumatology/ keq421.

22. Seo P. Pregnancy and vasculitis. Rheum Dis Clin N Am. 2007;33(2):299-317. https://doi.org/10.1016/j.rdc.2007.02.001.

23. Damian L, Pamfil C, Fodor M, Rogojan L, Hagau N, Rednic S. Polyarteritis nodosa in pregnancy. Ochsner J. 2018;18(1):94-7 Literature review of the 19 cases of PAN reported in pregnancy.

24. Pitkin RM. Polyarteritis nodosa. Clin Obstet Gynecol. 1983;26(3): 579-86.

25. Keir M, Bhagra C, Vatenmakher D, Arancibia-Galilea F, Jansen $\mathrm{K}$, Toh N, et al. Paediatric-onset coronary artery anomalies in pregnancy: a single-centre experience and systematic literature review. Cardiol Young. 2017;27(8):1529-37. https://doi.org/10. 1017/S1047951117000658.

26. Avila WS, Freire AFD, Soares AAS, Pereira A, Nicolau JC. Pregnancy in woman with Kawasaki disease and multiple coronary artery aneurysms. Arq Bras Cardiol. 2018;110(1):97-100. https://doi.org/10.5935/abc.20170185.

27. Youssef A, Ben Amara F, M'Barki M, Reziga H, Magherbi H, Neji K. Successful pregnancy and delivery in patient with artery bypass grafting for coronary lesion caused by Kawasaki disease. Tunis Med. 2013;91(3):217-8.

28. Gordon CT, Jimenez-Fernandez S, Daniels LB, Kahn AM, Tarsa M, Matsubara T, et al. Pregnancy in women with a history of Kawasaki disease: management and outcomes. BJOG. 2014;121(11):1431-8. https://doi.org/10.1111/1471-0528.12685.

29. Tsuda E, Kawamata K, Neki R, Echigo S, Chiba Y. Nationwide survey of pregnancy and delivery in patients with coronary arterial lesions caused by Kawasaki disease in Japan. Cardiol Young. 2006;16(2):173-8. https://doi.org/10.1017/S1047951106000126.

30. McCrindle BW, Rowley AH, Newburger JW, Burns JC, Bolger $\mathrm{AF}$, Gewitz M, et al. Diagnosis, treatment, and long-term management of Kawasaki disease: a scientific statement for health professionals from the American Heart Association. Circulation. 2017;135(17):e927-e99. https://doi.org/10.1161/CIR. 0000000000000484 .

31. Tsuda E, Ishihara Y, Kawamata K, Tsukano S, Negi R, Echigo S, et al. Pregnancy and delivery in patients with coronary artery lesions caused by Kawasaki disease. Heart. 2005;91(11):1481-2. https://doi.org/10.1136/hrt.2004.058842.
32. Bansal PJ, Tobin MC. Neonatal microscopic polyangiitis secondary to transfer of maternal myeloperoxidase-antineutrophil cytoplasmic antibody resulting in neonatal pulmonary hemorrhage and renal involvement. Ann Allergy Asthma Immunol. 2004;93(4): 398-401. https://doi.org/10.1016/S1081-1206(10)61400-7.

33. Oshima Y, Suwabe T, Marui Y, Hayami N, Hasegawa E, Yamanouchi M, et al. Microscopic polyangiitis necrotizing glomerulonephritis associated with pregnancy: case with a 20 -year clinical course and review of the literature. CEN Case Rep. 2018;7(2):274-81. https://doi.org/10.1007/s13730-018-0342-1.

34. Tuin J, Sanders JS, de Joode AA, Stegeman CA. Pregnancy in women diagnosed with antineutrophil cytoplasmic antibodyassociated vasculitis: outcome for the mother and the child. Arthritis Care Res (Hoboken). 2012;64(4):539-45. https://doi. org/10.1002/acr.21556.

35. Soh MC, Hart HH, Bass E, Wilkinson L. Pregnancy complicating Wegener's granulomatosis. Obstet Med. 2009;2(2):77-80. https:// doi.org/10.1258/om.2009.080053.

36. Grygiel-Gorniak B, Puszczewicz M. Granulomatosis with polyangiitis in pregnancy - clinical implications and treatment possibilities. Eur Rev Med Pharmacol Sci. 2015;19(13):2331-5 Review of the published case reports of MPA and pregnancy.

37. Fredi M, Lazzaroni MG, Tani C, Ramoni V, Gerosa M, Inverardi F, et al. Systemic vasculitis and pregnancy: a multicenter study on maternal and neonatal outcome of 65 prospectively followed pregnancies. Autoimmun Rev. 2015;14(8):686-91. https://doi.org/10. 1016/j.autrev.2015.03.009.

38. Corradi D, Maestri R, Facchetti F. Postpartum Churg-Strauss syndrome with severe cardiac involvement: description of a case and review of the literature. Clin Rheumatol. 2009;28(6):739-43. https://doi.org/10.1007/s10067-009-1143-x.

39. Matsuno O, Minamoto S. Flare of eosinophilic granulomatosis with polyangiitis related to pregnancy: case report and review of the literature. Respir Med Case Rep. 2019;26:23-6. https://doi. org/10.1016/j.rmcr.2018.10.027 Literature review of 16 pregnancies with EGPA.

40. Edwards MH, Curtis EM, Ledingham JM. Postpartum onset and subsequent relapse of eosinophilic granulomatosis with polyangiitis. BMJ Case Rep. 2015;2015. https://doi.org/10.1136/bcr-2015210373.

41. Qin J, Song G, Liu Q. Goodpasture's syndrome in early pregnancy: a case report. Exp Ther Med. 2018;15(1):407-11. https://doi. org/10.3892/etm.2017.5425.

42. Friend S, Carlan SJ, Wilson J, Madruga M. Reactivation of Goodpasture disease during the third trimester of pregnancy: a case report. J Reprod Med. 2015;60(9-10):449-51.

43. Huser M, Wagnerova K, Janku P, Malaskova L, Stourac P. Clinical management of pregnancy in women with Goodpasture syndrome. Gynecol Obstet Investig. 2015;79(2):73-7. https://doi. org/10.1159/000369998.

44. Thomson B, Joseph G, Clark WF, Hladunewich M, Patel A, Blake $\mathrm{P}$, et al. Maternal, pregnancy and fetal outcomes in de novo antiglomerular basement membrane antibody disease in pregnancy: a systematic review. Clin Kidney J. 2014;7(5):450-6. https://doi. org/10.1093/ckj/sfu086.

45. Gupta A, Gupta G, Marouf R. Cryoglobulinemic vasculitis in pregnancy. Int J Gynaecol Obstet. 2008;103(2):177-8. https:// doi.org/10.1016/j.ijgo.2008.05.027.

46. Sibilia J, Feugeas O, Laugel V, Dreval A, Messer J, Goetz J. Successful management of neonatal cryoglobulinaemia after a gemellar pregnancy in a woman with symptomatic type I cryoglobulinaemia. Ann Rheum Dis. 2004;63(2):217-8. https:// doi.org/10.1136/ard.2002.000174.

47. Juverdeanu S, Soydemir F, Baker P. Successful outcome of a pregnancy complicated by type 3 cryoglobulinaemia with 
negative hepatitis $\mathrm{C}$ virus (HCV) serology. J Obstet Gynaecol. 2008;28(2):233-4. https://doi.org/10.1080/01443610801916486.

48. Nossent J, Raymond W, Keen H, Inderjeeth C, Preen D. Pregnancy outcomes in women with a history of immunoglobulin A vasculitis. Rheumatology (Oxford). 2019;58(5):884-8. https:// doi.org/10.1093/rheumatology/key408 Largest cohort of pregnant women IgA vasculitis.

49. Tayabali S, Andersen K, Yoong W. Diagnosis and management of Henoch-Schonlein purpura in pregnancy: a review of the literature. Arch Gynecol Obstet. 2012;286(4):825-9. https://doi.org/10. 1007/s00404-012-2468-2.

50. Cote JM, Meunier RS, Tremblay JA, Weber F, Mahone M. Henoch-Schonlein purpura in pregnancy: a case report. Obstet Med. 2018;11(4):195-7. https://doi.org/10.1177/ $1753495 X 17745391$.

51. Sangle SR, Vounotrypidis P, Briley A, Nel L, Lutalo PM, Sanchez-Fernandez S, et al. Pregnancy outcome in patients with systemic vasculitis: a single-centre matched case-control study. Rheumatology (Oxford). 2015;54(9):1582-6. https://doi.org/10. 1093/rheumatology/kev018.

52.• Lee S, Czuzoj-Shulman N, Abenhaim HA. Behcet's disease and pregnancy: obstetrical and neonatal outcomes in a populationbased cohort of 12 million births. J Perinat Med. 2019;47(4): 381-7. https://doi.org/10.1515/jpm-2018-0161 One of the largest cohorts describing pregnancy outcomes in women with Behçet's disease.

53. Jadaon J, Shushan A, Ezra Y, Sela HY, Ozcan C, Rojansky N. Behcet's disease and pregnancy. Acta Obstet Gynecol Scand. 2005;84(10):939-44. https://doi.org/10.1111/j.0001-6349.2005. 00761.x.

54. Noel N, Wechsler B, Nizard J, Costedoat-Chalumeau N, Boutin du LT, Dommergues M, et al. Behcet's disease and pregnancy. Arthritis Rheum. 2013;65(9):2450-6. https://doi.org/10.1002/art. 38052.

55.• Orgul G, Aktoz F, Beksac MS. Behcet's disease and pregnancy: what to expect? J Obstet Gynaecol. 2018;38(2):185-8. https://doi. org/10.1080/01443615.2017.1336614 Study evaluating prenancy outcomes in BD and included a sub-group analysis of patients on colchicine.

56. Iskender C, Yasar O, Kaymak O, Yaman ST, Uygur D, Danisman N. Behcet's disease and pregnancy: a retrospective analysis of course of disease and pregnancy outcome. J Obstet Gynaecol Res. 2014;40(6):1598-602. https://doi.org/10.1111/jog.12386.

57. Gungor AN, Kalkan G, Oguz S, Sen B, Ozoguz P, Takci Z, et al. Behcet disease and pregnancy. Clin Exp Obstet Gynecol. 2014;41(6):617-9.

58. Marsal S, Falga C, Simeon CP, Vilardell M, Bosch JA. Behcet's disease and pregnancy relationship study. Br J Rheumatol. 1997;36(2):234-8. https://doi.org/10.1093/rheumatology/36.2. 234.

59. Uzun S, Alpsoy E, Durdu M, Akman A. The clinical course of Behcet's disease in pregnancy: a retrospective analysis and review of the literature. J Dermatol. 2003;30(7):499-502. https://doi.org/ 10.1111/j.1346-8138.2003.tb00423.x.

60. Riboni F, Cosma S, Perini PG, Benedetto C. Successful pregnancy in a patient with atypical Cogan's syndrome. Isr Med Assoc J. 2016;18(8):495-6.

61. Scherg F, Haag F, Krieger T. Off-label application of intravenous immunoglobulin (IVIG) for treatment of Cogan's syndrome during pregnancy. BMJ Case Rep. 2019;12(10). https://doi.org/10. 1136/bcr-2018-227917.

62. Gelfand ML, Kantor T, Gorstein F. Cogan's syndrome with cardiovascular involvement: aortic insufficiency. Bull N Y Acad Med. 1972;48(4):647-60.

63. Bernhardt D, Veltmann R, Dorwald R, Huth F. Cogan's syndrome with angitis of cranial nerves, aortitis, endocarditis, and glomerulonephritis (author's transl). Dtsch Med Wochenschr. 1976;101(10):373-7. https://doi.org/10.1055/s-0028-1104091.

64. Tarney CM, Wilson K, Sewell MF. Cogan syndrome in pregnancy. Obstet Gynecol. 2014;124(2 Pt 2 Suppl 1):428-31. https://doi. org/10.1097/AOG.0000000000000390.

65. Chen JS, Roberts CL, Simpson JM, March LM. Pregnancy outcomes in women with rare autoimmune diseases. Arthritis Rheumatol. 2015;67(12):3314-23. https://doi.org/10.1002/art. 39311.

66. Cobeta-Garcia JC, Garcia-Enguita P, Pina-Latorre MA, LerinSanchez FJ, Rodilla-Calvelo F. Ritodrine-induced leukocytoclastic vasculitis in pregnancy. Ann Pharmacother. 2004;38(1):66-9. https://doi.org/10.1345/aph.1D227.

67.• Sammaritano LR, Bermas BL, Chakravarty EE, Chambers C, Clowse MEB, Lockshin MD, et al. American College of Rheumatology guideline for the management of reproductive health in rheumatic and musculoskeletal diseases. Arthritis Rheumatol. 2020;2020. https://doi.org/10.1002/art.41191 New ACR guidelines on the management options of rheumatic diseases in pregnancy (not specifically for vasculitis; mostly for patients with systemic lupus and/or antiphospholipid syndrome).

68. Hviid A, Molgaard-Nielsen D. Corticosteroid use during pregnancy and risk of orofacial clefts. CMAJ. 2011;183(7):796-804. https://doi.org/10.1503/cmaj.101063.

69.• Tsao NW, Rebic N, Lynd LD, De Vera MA. Maternal and neonatal outcomes associated with biologic exposure before and during pregnancy in women with inflammatory systemic diseases: a systematic review and meta-analysis of observational studies. Rheumatology (Oxford). 2020. https://doi.org/10.1093/ rheumatology/keaa064 Meta-analysis of biologics exposure during pregnancy with adjustements for disease activity.

70. Pefanis A, Williams DS, Skrzypek H, Fung A, Paizis K. A case of ANCA-associated vasculitis presenting de novo in pregnancy, successfully treated with rituximab. Obstet Med. 2020;13(1):414. https://doi.org/10.1177/1753495X18780853.

71. Rolnik DL, Wright D, Poon LC, O'Gorman N, Syngelaki A, de Paco MC, et al. Aspirin versus placebo in pregnancies at high risk for preterm preeclampsia. N Engl J Med. 2017;377(7):613-22. https://doi.org/10.1056/NEJMoa1704559.

72. Roberge S, Bujold E, Nicolaides KH. Aspirin for the prevention of preterm and term preeclampsia: systematic review and meta-analysis. Am J Obstet Gynecol. 2018;218(3):287-93.e1. https://doi. org/10.1016/j.ajog.2017.11.561.

73. D'Souza R, Kingdom J. Preeclampsia. CMAJ. 2016;188(16): 1178. https://doi.org/10.1503/cmaj.151551.

74. Bang D, Chun YS, Haam IB, Lee ES, Lee S. The influence of pregnancy on Behcet's disease. Yonsei Med J. 1997;38(6):43743. https://doi.org/10.3349/ymj.1997.38.6.437.

75. Gul U. Pregnancy and Behcet disease. Arch Dermatol. 2000;136(8):1063-4. https://doi.org/10.1001/archderm.136.8. 1063.

76. Martin JA, Hamilton BE, Osterman MJK, Driscoll AK, Drake P. Births: final data for 2017. Natl Vital Stat Rep. 2018;67(8):1-50.

77. Yilmaz ZV, Turkmen GG, Yilmaz E, Daglar K, Kirbas A, Sanhal $\mathrm{C}$, et al. Influence of Behcet's disease on first and second trimester serum screening markers. J Obstet Gynaecol Res. 2017;43(3): 511-5. https://doi.org/10.1111/jog.13237.

78. Farrag OA, Al-Suleiman SA, Bella H, Al-Omari H. Behcet disease in pregnancy. Aust N Z J Obstet Gynaecol. 1987;27(2):1613. https://doi.org/10.1111/j.1479-828x.1987.tb00972.x.

79. Madkour M, Kudwah A. Behcet's disease. Br Med J. 1978;2(6154):1786. https://doi.org/10.1136/bmj.2.6154.1786-a.

80. Hamza M, Elleuch M, Zribi A. Behcet's disease and pregnancy. Ann Rheum Dis. 1988;47(4):350. https://doi.org/10.1136/ard.47. 4.350-a. 
81. Hiwarkar P, Stasi R, Sutherland G, Shannon M. Deep vein and intracardiac thrombosis during the post-partum period in Behcet's disease. Int J Hematol. 2010;91(4):679-86. https://doi.org/10. 1007/s12185-010-0538-4.

82. Chan WS, Rey E, Kent NE, Group VTEiPGW, Chan WS, Kent NE, et al. Venous thromboembolism and antithrombotic therapy in pregnancy. J Obstet Gynaecol Can. 2014;36(6):527-53. https:// doi.org/10.1016/s1701-2163(15)30569-7.

83. Martineau M, Haskard DO, Nelson-Piercy C. Behcet's syndrome in pregnancy. Obstet Med. 2010;3(1):2-7. https://doi.org/10. 1258/om.2009.090033.

84.• Indraratna PL, Virk S, Gurram D, Day RO. Use of colchicine in pregnancy: a systematic review and meta-analysis. Rheumatology (Oxford). 2018;57(2):382-7. https://doi.org/10.1093/ rheumatology/kex353 Meta-analysis evaluating the safety of colchicine in pregnancy.

85. Diav-Citrin O, Otcheretianski-Volodarsky A, Shechtman S, Ornoy A. Pregnancy outcome following gestational exposure to TNF-alpha-inhibitors: a prospective, comparative, observational study. Reprod Toxicol. 2014;43:78-84. https://doi.org/10.1016/j. reprotox.2013.11.004.

86. Hatemi G, Mahr A, Ishigatsubo Y, Song YW, Takeno M, Kim D, et al. Trial of apremilast for oral ulcers in Behcet's syndrome. N Engl J Med. 2019;381(20):1918-28. https://doi.org/10.1056/ NEJMoa1816594.

87. Metodiev Y, Walker T. Anaesthetic considerations in a parturient with Behcet's disease. Int J Obstet Anesth. 2018;33:93-4. https:// doi.org/10.1016/j.ijoa.2017.06.010.

88. Thubert T, Donnadieu AC, Dupont-Bernabe C, Even M, Fior R, Pasquali JL, et al. Behcet's disease in obstetrics and gynecology. J Gynecol Obstet Biol Reprod (Paris). 2011;40(4):283-90. https:// doi.org/10.1016/j.jgyn.2010.06.012.

89. Antonelou M, Braha N. Transient neonatal Behcet's disease. BMJ Case Rep. 2013;2013. https://doi.org/10.1136/bcr-2012-007589.

90. Jog S, Patole S, Koh G, Whitehall J. Unusual presentation of neonatal Behcets disease. Am J Perinatol. 2001;18(5):287-92. https://doi.org/10.1055/s-2001-16994.

91. Stark AC, Bhakta B, Chamberlain MA, Dear P, Taylor PV. Lifethreatening transient neonatal Behcet's disease. Br J Rheumatol. 1997;36(6):700-2. https://doi.org/10.1093/rheumatology/36.6. 700 .

92. Hwang I, Lee CK, Yoo B, Lee I. Necrotizing villitis and decidual vasculitis in the placentas of mothers with Behcet disease. Hum Pathol. 2009;40(1):135-8. https://doi.org/10.1016/j.humpath. 2008.04.021.

93. Hidaka N, Yamanaka Y, Fujita Y, Fukushima K, Wake N. Clinical manifestations of pregnancy in patients with Takayasu arteritis: experience from a single tertiary center. Arch Gynecol Obstet. 2012;285(2):377-85. https://doi.org/10.1007/s00404011-1992-9.

94. Alpay-Kanitez N, Omma A, Erer B, Artim-Esen B, Gul A, Inanc $\mathrm{M}$, et al. Favourable pregnancy outcome in Takayasu arteritis: a single-centre experience. Clin Exp Rheumatol. 2015;33(2 Suppl 89):S-7-10.

95. Singh N, Tyagi S, Tripathi R, Mala YM. Maternal and fetal outcomes in pregnant women with Takayasu aortoarteritis: does optimally timed intervention in women with renal artery involvement improve pregnancy outcome? Taiwan J Obstet Gynecol. 2015;54(5):597-602. https://doi.org/10.1016/j.tjog.2015.08.014.

96. Kirshenbaum M, Simchen MJ. Pregnancy outcome in patients with Takayasu's arteritis: cohort study and review of the literature.
J Matern Fetal Neonatal Med. 2018;31(21):2877-83. https://doi. org/10.1080/14767058.2017.1359529 Retrospective study evaluating pregnancy outcomes in $\mathbf{2 0}$ pregnancies with TAK.

97. de Jesus GR, d'Oliveira IC, dos Santos FC, Rodrigues G, Klumb EM, de Jesus NR, et al. Pregnancy may aggravate arterial hypertension in women with Takayasu arteritis. Isr Med Assoc J. 2012;14(12):724-8.

98. Sibai B, Dekker G, Kupferminc M. Pre-eclampsia. Lancet. 2005;365(9461):785-99. https://doi.org/10.1016/S01406736(05)17987-2.

99. Jacquemyn Y, Vercauteren M. Pregnancy and Takayasu's arteritis of the pulmonary artery. J Obstet Gynaecol. 2005;25(1):63-5. https://doi.org/10.1080/01443610400026042.

100. Mandal D, Mandal S, Dattaray C, Banerjee D, Ghosh P, Ghosh A, et al. Takayasu arteritis in pregnancy: an analysis from eastern India. Arch Gynecol Obstet. 2012;285(3):567-71. https://doi. org/10.1007/s00404-011-1998-3.

101. Tanaka H, Tanaka K, Kamiya C, Iwanaga N, Yoshimatsu J. Analysis of pregnancies in women with Takayasu arteritis: complication of Takayasu arteritis involving obstetric or cardiovascular events. J Obstet Gynaecol Res. 2014;40(9):2031-6. https://doi. org/10.1111/jog.12443.

102. Matsumura A, Moriwaki R, Numano F. Pregnancy in Takayasu arteritis from the view of internal medicine. Heart Vessels Suppl. 1992;7:120-4. https://doi.org/10.1007/bf01744557.

103.• Gudbrandsson B, Wallenius M, Garen T, Henriksen T, Molberg $\mathrm{O}$, Palm O. Takayasu arteritis and pregnancy: a population-based study on outcomes and mother/child-related concerns. Arthritis Care Res (Hoboken). 2017;69(9):1384-90. https://doi.org/10. 1002/acr.23146 Study on pregnancy outcomes that also compared outcomes in patients with TAK before and after diagnosis.

104. Ishikawa K, Matsuura S. Occlusive thromboaortopathy (Takayasu's disease) and pregnancy. Clinical course and management of 33 pregnancies and deliveries. Am J Cardiol. 1982;50(6): 1293-300. https://doi.org/10.1016/0002-9149(82)90466-0.

105.• Veltri NL, Hladunewich M, Bhasin A, Garland J, Thomson B. De novo antineutrophil cytoplasmic antibody-associated vasculitis in pregnancy: a systematic review on maternal, pregnancy and fetal outcomes. Clin Kidney J. 2018;11(5):659-66. https://doi.org/10. 1093/ckj/sfy011 A review of AAV diagnosis de novo during pregnancy showing worse pregnancy outcomes.

106.• Singh P, Dhooria A, Rathi M, Agarwal R, Sharma K, Dhir V, et al. Successful treatment outcomes in pregnant patients with ANCAassociated vasculitides: a systematic review of literature. Int $\mathrm{J}$ Rheum Dis. 2018;21(9):1734-40. https://doi.org/10.1111/1756185X.13342 Extensive review of $\mathbf{1 3 7}$ pregnancies with AAV and pregnancy outcomes.

107. Croft AP, Smith SW, Carr S, Youssouf S, Salama AD, Burns A, et al. Successful outcome of pregnancy in patients with antineutrophil cytoplasm antibody-associated small vessel vasculitis. Kidney Int. 2015;87(4):807-11. https://doi.org/10.1038/ki.2014. 329.

108. Engel NM, Gramke HF, Peeters L, Marcus MA. Combined spinalepidural anaesthesia for a woman with Wegener's granulomatosis with subglottic stenosis. Int J Obstet Anesth. 2011;20(1):94-5. https://doi.org/10.1016/j.ijoa.2010.07.003.

Publisher's Note Springer Nature remains neutral with regard to jurisdictional claims in published maps and institutional affiliations. 